\title{
A MODEL FOR THE SIMULATION OF THE SHARON PROCESS: pH AS A KEY FACTOR
}

\author{
Albert Magría, Lluís Corominas ${ }^{b}$, Helio López ${ }^{b}$, Elena Campos ${ }^{\text {a }}$, Marilós Balaguer \\ Jesús Colprim ${ }^{\mathrm{b}}$ and Xavier Flotats ${ }^{\mathrm{a}}$ \\ ${ }^{a}$ Laboratory of Environmental Engineering (LEA), Centre UdL-IRTA. University of Lleida. \\ Av. Rovira Roure 191, E-25198 Lleida, Spain (e-mail: albert.magri@irta.es) \\ ${ }^{\mathrm{b}}$ Chemical and Environmental Engineering Laboratory (LEQUIA). EQATA Department. University of Girona. \\ Campus Montilivi s/n, E-17071 Girona, Spain
}

\begin{abstract}
The SHARON process allows partial nitrification of wastewaters with high ammonium content and, when coupled with the Anammox process, is a more sustainable alternative for N-removal than a conventional nitrification-denitrification. A mathematical model describing a continuously aerated SHARON reactor is presented. Haldane kinetics is used in both steps of the nitrification, since ammonium-oxidizing and nitrite-oxidizing organisms are inhibited by their own substrates. Special attention is given to $\mathrm{pH}$ because it is a key factor, implementing an algorithm for its calculation. A preliminary evaluation of the model using synthetic feed is presented.
\end{abstract}

Keywords: mathematical modelling; SHARON; substrate inhibition; $\mathrm{pH}$ simulation

\section{INTRODUCTION}

Efficient nitrogen removal represents an important challenge in modern wastewater treatment systems. Ammonium has been traditionally eliminated by a combination of two different biological processes: nitrification and denitrification. The need to find more sustainable alternatives has led to a new, totally autotrophic, combined process: the SHARON-Anammox process (van Dongen et al., 2001).

In the SHARON (Single reactor system for High Ammonium Removal Over Nitrite) process, ammonium is converted to nitrite (partial nitrification) by ammonium-oxidising bacteria in a reactor without sludge retention, under aerobic conditions and at relatively high temperature $\left(\sim 35^{\circ} \mathrm{C}\right)$. Besides dissolved oxygen concentration, temperature and hydraulic residence time, $\mathrm{pH}$ is also a main process parameter (Hellinga et al., 1999). Inorganic carbon may also become a limiting factor for the autotrophic biomass (Wett and Rauch, 2003). Nitrite-oxidisers do not interfere when the process is well controlled due to the short residence time and the high temperature. The SHARON process is especially suitable for the treatment of wastewater streams with high ammonium content, allowing savings of $25 \%$ of the oxygen required to ensure complete nitrification.

By modelling it is possible to develop mathematical tools for the integration of knowledge relating to specific phenomena. Modelling assists in the design of experiments and the evaluation of experimental results, as well as in testing hypotheses. It also helps to reveal relationships between different variables, to predict the evolution of the system, and in the design of optimised processes and management strategies.

The aim of this work was to develop a mathematical model for the SHARON process, applied to the treatment of N-rich wastewaters which also contained organic matter and phosphorus. The proposed 
model had to be able to predict the dynamic evolution of $\mathrm{pH}$, a key factor in the process. A preliminary evaluation of the model using synthetic feed was also performed.

\section{DEVELOPMENT OF THE MODEL}

\subsection{Components and processes}

Literature on activated sludge models ASMx (Henze et al., 1987; Henze et al., 1995a) and on specific models of the SHARON process such as those of Hellinga et al. (1999), Volcke et al. (2002) and Van Hulle et al. (2004) were taken as the bases for the development of a new model for the simulation of the treatment of wastewaters with high nitrogen concentration, containing organic matter and phosphorus. Sixteen components were established (Table 1), which were involved in ten different biochemical and physical processes with the corresponding reaction rates $\rho_{\mathrm{j}}$ listed in Table 2. Soluble components $\mathrm{S}$ and particulate components $\mathrm{X}$ were distinguished. Some of the soluble components should be split into different species according to the chemical equilibrium specified further on (Table 3). Only aerobic conditions were assumed.

Table 1. Components of the model

\begin{tabular}{|c|c|c|c|}
\hline Components & Definition & Units & Chemical species included \\
\hline \multicolumn{4}{|c|}{ Soluble $\left(\mathrm{n}_{\mathrm{s}}=10\right)$} \\
\hline 1. $\mathrm{S}_{\mathrm{O} 2}$ & Dissolved oxygen & $\mathrm{mg} \mathrm{O}_{2} \mathrm{l}^{-1}$ & $\mathrm{O}_{2}$ \\
\hline 2. $\mathrm{S}_{\mathrm{IC}}$ & Inorganic carbon & $\mathrm{mg} \mathrm{Cl}^{-1}$ & $\mathrm{H}_{2} \mathrm{CO}_{3}-\mathrm{C}+\mathrm{CO}_{2}-\mathrm{C}+\mathrm{HCO}_{3}^{-}-\mathrm{C}+\mathrm{CO}_{3}{ }^{2-}-\mathrm{C}$ \\
\hline 3. $\mathrm{S}_{\mathrm{I}}$ & Inert soluble organic material & $\mathrm{mg} \mathrm{COD}^{-1}$ & - \\
\hline 4. $\mathrm{S}_{\mathrm{S}}$ & Readily biodegradable organic substrates & $\mathrm{mg} \mathrm{COD}^{-1}$ & $\Sigma \mathrm{A}_{i} \mathrm{H}-\mathrm{COD}+\Sigma \mathrm{A}_{i}^{-}-\mathrm{COD}+\mathrm{RS}_{\mathrm{S}}-\mathrm{COD}$ \\
\hline 5. $\mathrm{S}_{\mathrm{NH} 4}$ & Total ammonium & $\operatorname{mg~N~} 1^{-1}$ & $\mathrm{NH}_{3}-\mathrm{N}+\mathrm{NH}_{4}^{+}-\mathrm{N}$ \\
\hline 6. $\mathrm{S}_{\mathrm{NO} 2}$ & Total nitrite & $\mathrm{mg} \mathrm{N}^{-1}$ & $\mathrm{HNO}_{2}-\mathrm{N}+\mathrm{NO}_{2}^{-}-\mathrm{N}$ \\
\hline 7. $\mathrm{S}_{\mathrm{NO} 3}$ & Nitrate & $\mathrm{mg} \mathrm{N}^{-1}$ & $\mathrm{NO}_{3}{ }^{-}-\mathrm{N}$ \\
\hline 8. $\mathrm{S}_{\mathrm{PO} 4}$ & Inorganic soluble phosphorus & $\mathrm{mg} \mathrm{P}^{-1}$ & $\mathrm{H}_{3} \mathrm{PO}_{4}-\mathrm{P}+\mathrm{H}_{2} \mathrm{PO}_{4}^{-}-\mathrm{P}+\mathrm{HPO}_{4}{ }^{2-}-\mathrm{P}+\mathrm{PO}_{4}^{3-}-\mathrm{P}$ \\
\hline 9. $\mathrm{S}_{\mathrm{Z}}$ & Additional positive charges & $\operatorname{mol~Z} \mathrm{Z}^{+1}$ & - \\
\hline 10. $\mathrm{S}_{\mathrm{H}}$ & Protons & $\mathrm{mol} \mathrm{H}^{+} 1^{-1}$ & $\mathrm{H}^{+}$ \\
\hline \multicolumn{4}{|c|}{ Particulate $\left(\mathrm{n}_{\mathrm{p}}=6\right)$} \\
\hline 11. $X_{I}$ & Inert particulate organic material & $\mathrm{mg} \mathrm{COD}^{-1}$ & - \\
\hline 12. $\mathrm{X}_{\mathrm{S}}$ & Slowly biodegradable organic substrates & $\mathrm{mg} \mathrm{COD}^{-1}$ & - \\
\hline 13. $\mathrm{X}_{\mathrm{H}}$ & Heterotrophic organisms & $\mathrm{mg} \mathrm{COD}^{-1}$ & - \\
\hline 14. $\mathrm{X}_{\mathrm{AO}}$ & Ammonium-oxidizing organisms & $\mathrm{mg} \mathrm{COD}^{-1}$ & - \\
\hline 15. $\mathrm{X}_{\mathrm{NO}}$ & Nitrite-oxidizing organisms & $\mathrm{mg} \mathrm{COD}^{-1}$ & - \\
\hline 16. $X_{\mathrm{TSS}}$ & Total suspended solids & $\operatorname{mg~TSS~} 1^{-1}$ & - \\
\hline
\end{tabular}

The hydrolysis of slowly biodegradable organic substrates $\mathrm{X}_{\mathrm{S}}$ to readily biodegradable organic substrates $\mathrm{S}_{\mathrm{S}}$ was modelled by means of Contois kinetics. No nutrient limitations were considered for the growth processes since sufficiently high concentrations were expected. Ammoniumoxidizing organisms $\mathrm{X}_{\mathrm{AO}}$ are expected to transform $\mathrm{S}_{\mathrm{NH} 4}$ to $\mathrm{S}_{\mathrm{NO} 2}$ using ammonia $\left(\mathrm{NH}_{3}\right)$ as substrate (nitritation). On the other hand, nitrite-oxidizing organisms $\mathrm{X}_{\mathrm{NO}}$ are expected to oxidize $\mathrm{S}_{\mathrm{NO} 2}$ to $\mathrm{S}_{\mathrm{NO} 3}$ using nitrous acid $\left(\mathrm{HNO}_{2}\right)$ as substrate (nitratation). Both autotrophic populations can be inhibited by ammonia and nitrous acid. Carrera et al. (2004), among other authors, confirmed that the Haldane model describes nitritation inhibition by $\mathrm{NH}_{3}$ and nitratation inhibition by $\mathrm{HNO}_{2}$ quite well. Therefore, specific kinetic rates including a Haldane term for the corresponding substrate and a non-competitive reversible inhibitory (NOCRI) function for the other inhibitory specie were used. It is interesting to remark that by maintaining the same values for the kinetic parameters, the behaviour predicted by Haldane kinetics was different from that simulated by the product of a Monod term and a NOCRI function (Figure 1). This fact makes the comparison of parameter values dependent on the kinetics used. Lysis processes were considered in contrast to other SHARON modelling references. The influence of the $\mathrm{pH}$ on the growth processes was taken into account by applying a fitting function (Henze et al., 1995b). An optimal $\mathrm{pH}\left(\mathrm{pH}_{\mathrm{opt}}\right)$ of 7.23 was adopted, regardless of the kind of organism. 


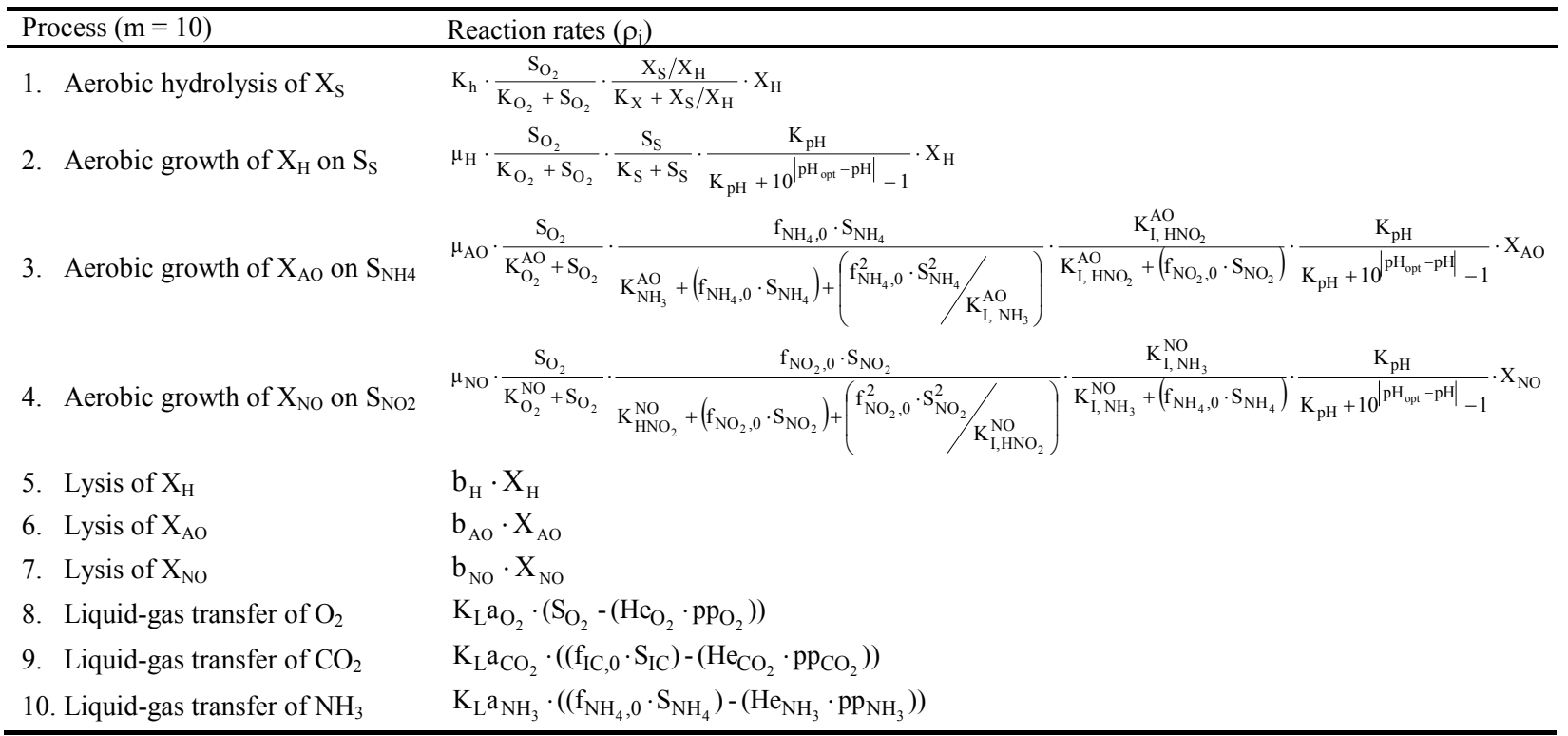

It was considered that the component $\mathrm{S}_{\mathrm{S}}$ included the volatile fatty acids $\left(\mathrm{A}_{i} \mathrm{H}\right)$ acetic, propionic, butyric and valeric acids plus a pool of other non-ionizable organic substrates $\left(\mathrm{RS}_{\mathrm{S}}\right)$. Weighting factors $\lambda_{\mathrm{A} i}\left(\mathrm{~mol} \mathrm{VFA} \mathrm{mol}^{-1} \mathrm{VFA}\right)$ were also defined $\left(\Sigma \lambda_{\mathrm{A} i}=1\right)$. Inorganic carbon $\mathrm{S}_{\mathrm{IC}}$, protons $\mathrm{S}_{\mathrm{H}}$ and additional positive charges $\mathrm{S}_{Z}$ were included in the model. Unlike in ASMx models, alkalinity was not considered as a component. $\mathrm{S}_{\mathrm{H}}$ was directly related to the $\mathrm{pH}$ value and $\mathrm{S}_{\mathrm{Z}}$ represented the amount of additional positive charges and made it possible to close the charge balance. This component could be negative if there were more negative than positive additional charges in the medium. Its value depends exclusively on the composition of the inlet flow and the initial concentration inside the reactor. Using the charge balance equation it is possible to calculate both concentrations. Liquid-gas transfer processes were included in the model using the two-film theory. The partial pressures (pp) considered were $2.1 \cdot 10^{-1}$ atm $\left(\mathrm{O}_{2}\right), 3.0 \cdot 10^{-4} \mathrm{~atm}\left(\mathrm{CO}_{2}\right)$ and $0.0 \mathrm{~atm}\left(\mathrm{NH}_{3}\right)$. Henry's law constants $(\mathrm{He})$ were calculated as a function of temperature. In the future, other processes such as denitrification or chemical precipitations might be introduced into the model.

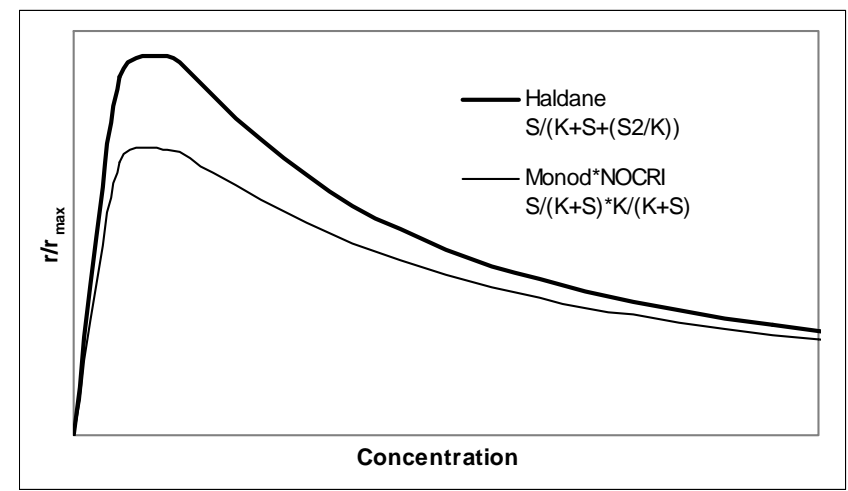

Figure 1. Substrate inhibition, Haldane kinetic vs. the product of a Monod term and a non-competitive reversible inhibition (NOCRI) function assuming the same inhibition/saturation constant K

The effect of temperature on kinetic parameters (hydrolysis rate constant, maximum growth rates, decay rates and liquid-gas transfer coefficients) was included in the model by incorporating an Arrhenius type equation $\left(\mathrm{K}_{\mathrm{T}}=\mathrm{K}_{293} \cdot \mathrm{e}^{\theta \cdot(\mathrm{T}-293)}\right)$. The values of the constant $\theta$ were adopted from Henze et al. (1995a) for hydrolysis (0.039) and heterotrophic organisms (0.068) and from Wyffels et al. (2003) for ammonium-oxidizers (0.094), nitrite-oxidizers (0.061) and liquid-gas transfer (-0.039). 


\subsection{Chemical equilibrium}

The acid-base equilibrium reactions considered are listed in Table 3. Dissociations were assumed to occur instantaneously and to be affected by temperature, $\mathrm{pH}$ and ionic strength. Dissociation constants $\left(\mathrm{K}_{\mathrm{d}}\right)$ were calculated as a function of temperature, using the equations proposed by Musvoto et al. (2000) for inorganic carbon and phosphorus, Lide (1993) for VFAs, Anthonisen et al. (1976) for nitrogen and Snoeyink and Jenkins (1980) for water. The concentration of species such as $\mathrm{NH}_{3}$ and $\mathrm{HNO}_{2}$ affects the kinetics of autotrophic organisms since they are both substrate and inhibitor simultaneously. Furthermore, $\mathrm{NH}_{3}$ and $\mathrm{CO}_{2}$ are involved in gas transport processes. Table 4 presents the matrix $\mathrm{F}\left(\mathrm{f}_{\mathrm{s}, \mathrm{ch}}\right)$ for the calculation of the dissociation fractions associated with the soluble components, which is also included in the $\mathrm{pH}$ calculation algorithm. Soluble components are in rows and ionic charges in columns. It is important to notice that the sum of each row must be equal to one. The matrix notation presented for matrix $\mathrm{F}$ helps in the comprehension of the model and facilitates future incorporations of other equilibrium reactions affecting $\mathrm{pH}$.

Table 3. Chemical equilibrium reactions included in the model

\begin{tabular}{ll}
\hline Reference element & Equilibrium \\
\hline Carbon (inorganic) & $\mathrm{H}_{2} \mathrm{CO}_{3}^{*} \stackrel{\mathrm{K}_{\mathrm{Cl}}}{\longrightarrow} \mathrm{HCO}_{3}^{-}+\mathrm{H}^{+} \stackrel{\mathrm{K}_{\mathrm{C} 2}}{\longrightarrow} \mathrm{CO}_{3}^{2-}+2 \mathrm{H}^{+}$ \\
Carbon (VFA) & $\mathrm{A}_{i} \mathrm{H} \stackrel{\mathrm{K}_{\mathrm{Ai}}}{\longrightarrow} \mathrm{A}_{i}^{-}+\mathrm{H}^{+}$ \\
Nitrogen (ammonium) & $\mathrm{NH}_{4}^{+} \stackrel{\mathrm{K}_{\mathrm{NH}}}{\longrightarrow} \mathrm{NH}_{3}+\mathrm{H}^{+}$ \\
Nitrogen (nitrite) & $\mathrm{HNO}_{2} \stackrel{\mathrm{K}_{\mathrm{NO}}}{\longleftrightarrow} \mathrm{NO}_{2}^{-}+\mathrm{H}^{+}$ \\
Phosphorus & $\mathrm{H}_{3} \mathrm{PO}_{4} \stackrel{\mathrm{K}_{\mathrm{Pl}}}{\longleftrightarrow} \mathrm{H}_{2} \mathrm{PO}_{4}^{-}+\mathrm{H}^{+} \stackrel{\mathrm{K}_{\mathrm{P} 2}}{\longleftrightarrow} \mathrm{HPO}_{4}^{2-}+2 \mathrm{H}^{+} \stackrel{\mathrm{K}_{\mathrm{P} 3}}{\longleftrightarrow} \mathrm{PO}_{4}^{3-}+3 \mathrm{H}^{+}$ \\
Water & $\mathrm{H}_{2} \mathrm{O} \stackrel{\mathrm{K}_{\mathrm{W}}}{\longleftrightarrow} \mathrm{OH}^{-}+\mathrm{H}^{+}$ \\
\hline
\end{tabular}

$\mathrm{H}_{2} \mathrm{CO}_{3}^{*}=\mathrm{H}_{2} \mathrm{CO}_{3}+\mathrm{CO}_{2}(a q)$

The activity and concentration of chemical species are related through the activity coefficient $\gamma$, as proposed by Snoeyink and Jenkins (1980). The value of these factors depends on the ionic strength (I) of the medium. Eq. 1 allows the calculation of the activity factors as a function of the corresponding ionic charge $(\mathrm{Ch})$ when $\mathrm{I} \S 0.1 \mathrm{M}$. Other expressions should be used at higher ionic strengths. Thus, dissociation constants must be corrected with the activity factors of the chemical species involved $\left(\mathrm{K}_{\mathrm{d}}^{\mathrm{c}}\right)$.

$\log _{10} \gamma_{1}=-\frac{1}{2} \mathrm{Ch}_{1}^{2} \cdot \frac{\sqrt{\mathrm{I}}}{1+\sqrt{\mathrm{I}}}$

Table 4. Matrix F for the calculation of the dissociation fractions $\left(\mathrm{f}_{\mathrm{s}, \mathrm{ch}}\right)$

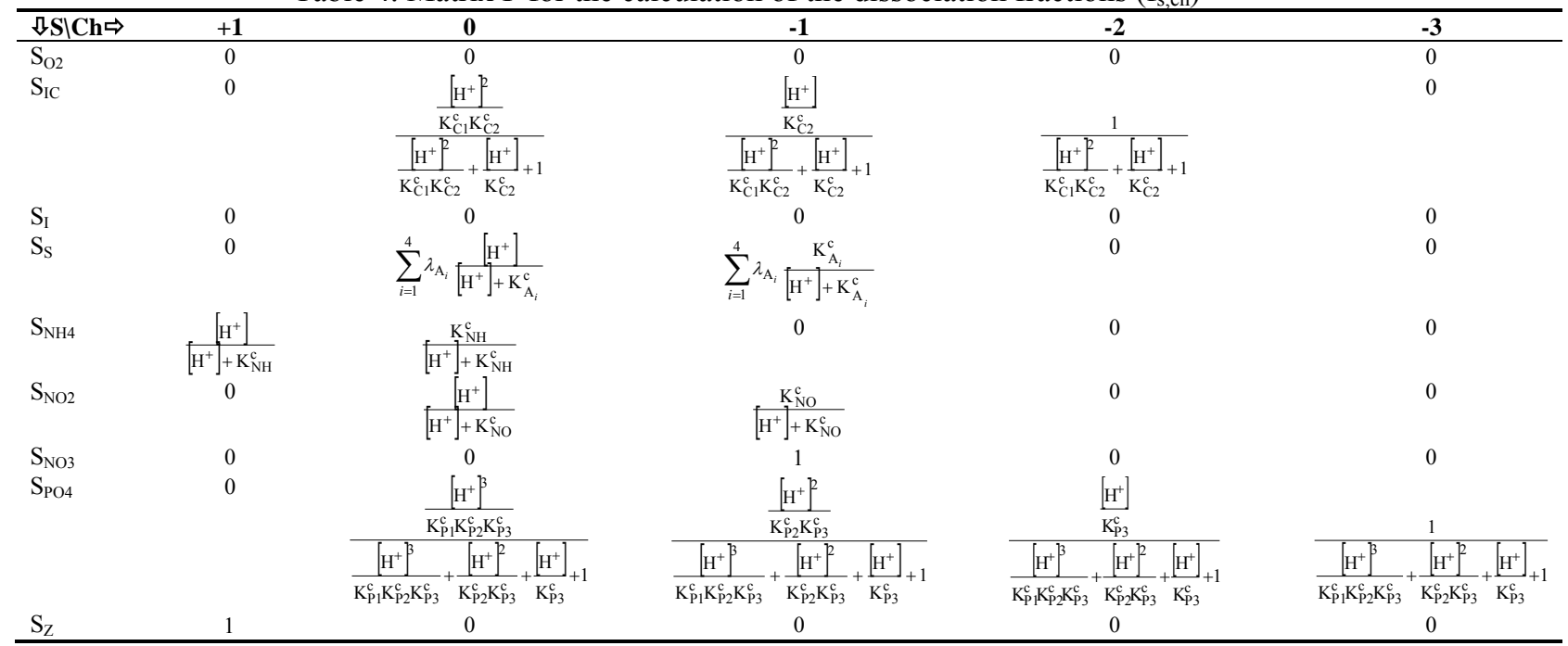




\subsection{Mass balance}

The modelled SHARON reactor had the configuration of a perfect Continuously Stirred Tank Reactor (CSTR) system without sludge retention. The Ordinary Differential Equation (ODE) describing the temporal evolution of each component $\mathrm{C}_{\mathrm{i}}$, except for protons, takes the general form of Eq. 2, where $\mathrm{Q}$ is the liquid flow, $\mathrm{V}_{\mathrm{L}}$ the liquid phase volume assumed to be constant, $\mathrm{r}_{\mathrm{i}}$ the volumetric conversion rate and $v_{\mathrm{ji}}$ the stoichiometric matrix. Conservation equations were applied in each process for COD, C, N, P and TSS.

$$
\frac{\mathrm{dC}_{\mathrm{i}}}{\mathrm{dt}}=\left(\mathrm{C}_{\mathrm{in}}-\mathrm{C}_{\mathrm{i}}\right) \cdot \frac{\mathrm{Q}}{\mathrm{V}_{\mathrm{L}}}+\mathrm{r}_{\mathrm{i}}=\left(\mathrm{C}_{\mathrm{inn}}-\mathrm{C}_{\mathrm{i}}\right) \cdot \frac{\mathrm{Q}}{\mathrm{V}_{\mathrm{L}}}+\sum_{\mathrm{j}=1}^{10} \mathrm{v}_{\mathrm{ji}} \cdot \rho_{\mathrm{j}}
$$

\subsection{Calculation of the $\mathrm{pH}$}

An algorithm for the dynamic calculation of the $\mathrm{pH}$ was also implemented. This algorithm was initially developed by Campos and Flotats (2003) and applied in the simulation of the anaerobic digestion process. In this paper it has been improved and adapted to the SHARON process. From the charge balance equation it was possible to define a new $\mathrm{pH}$ dependent variable called net charge (NC) as shown in Eq. 3:

$$
\mathrm{NC}=\left[\mathrm{H}^{+}\right]-\left[\mathrm{OH}^{-}\right]=\left[\mathrm{HCO}_{3}^{-}\right]+2\left[\mathrm{CO}_{3}^{2-}\right]+\sum_{i=1}^{4}\left[\mathrm{~A}_{i}^{-}\right]+\left[\mathrm{NO}_{2}^{-}\right]+\left[\mathrm{NO}_{3}^{-}\right]+\left[\mathrm{H}_{2} \mathrm{PO}_{4}^{-}\right]+2\left[\mathrm{HPO}_{4}^{2-}\right]+3\left[\mathrm{PO}_{4}^{3-}\right]-\left[\mathrm{NH}_{4}^{+}\right]-\left[\mathrm{Z}^{+}\right]
$$

The proton concentration is therefore a function of the net charge: $\left[\mathrm{H}^{+}\right]=\psi(\mathrm{NC})$, where $\psi(\mathrm{NC})$ takes a different form depending on whether $\mathrm{NC}$ is positive or negative. It was then possible to establish an ODE for the temporal evolution of $\left[\mathrm{H}^{+}\right]$(Eq. 4):

$$
\frac{\mathrm{d}\left[\mathrm{H}^{+}\right]}{\mathrm{dt}}=\frac{\mathrm{dS}_{\mathrm{H}}}{\mathrm{dt}}=\frac{-\frac{\mathrm{dSC}^{\mathrm{t}}}{\mathrm{dt}} \cdot \mathrm{F} \cdot \mathrm{IC}}{\mathrm{B}^{-1}+\left(\mathrm{SC}^{\mathrm{t}} \cdot \mathrm{F}^{\prime} \cdot \mathrm{IC}\right)}
$$

Where $\mathrm{SC}^{\mathrm{t}}$ is the transposed vector of the soluble components expressed in units of mol $\mathrm{l}^{-1}$, and IC the vector of the ionic charges. $\mathrm{B}$ is the derivative of $\psi$ with respect to $\mathrm{NC}$, with its calculation depending on whether $\mathrm{NC}$ is positive or negative. It is also necessary to calculate the matrix $\mathrm{F}^{\prime}=$ $\mathrm{dF} / \mathrm{d}\left[\mathrm{H}^{+}\right]$. Finally, $\mathrm{pH}$ can be calculated from $\left[\mathrm{H}^{+}\right]$, considering the respective activity factor (Eq. 5).

$$
\mathrm{pH}=-\log _{10}\left\{\mathrm{H}^{+}\right\}=-\log _{10}\left(\gamma_{\mathrm{H}^{+}} \cdot\left[\mathrm{H}^{+}\right]\right)
$$

\subsection{Computational implementation}

FORTRAN language and Microsoft Excel as workspace interface were used in the computational implementation of the model. The solution of the system of ODEs defining the evolution of the 16 components considered was numerically approximated by means of the Runge-Kutta-Fehlberg adaptive step-size integration method (Sewell, 1988).

\section{EXPERIMENTAL DATA SOURCE}

\subsection{The SHARON pilot-plant}

The SHARON process was operated at lab-scale in a CSTR with an approximated hydraulic residence time of 2 days. Synthetic substrate, mainly composed of ammonium and sodium 
bicarbonate, was used throughout the experimental period. The formation of a biofilm inside the reactor was detected. For this reason, it was necessary to carry out periodical cleanings.

The SHARON pilot-plant (Figure 2) consisted of a stainless steel reactor with a working volume of 22.5 1. It was located in a $20^{\circ} \mathrm{C}$ thermostated lab, and the temperature inside the reactor was controlled by means of an electrical resistance. The synthetic substrate was fed into the system using a peristaltic pump. Air was supplied through diffusers located at the bottom of the reactor. The pilot-plant was equipped with a monitoring and control scheme consisting of two interface cards (PCL-812 PG and PCLD-885 from Advantech) and an own software programme developed using LabWindows. On-line monitoring of $\mathrm{pH}$, dissolved oxygen and temperature was carried out.

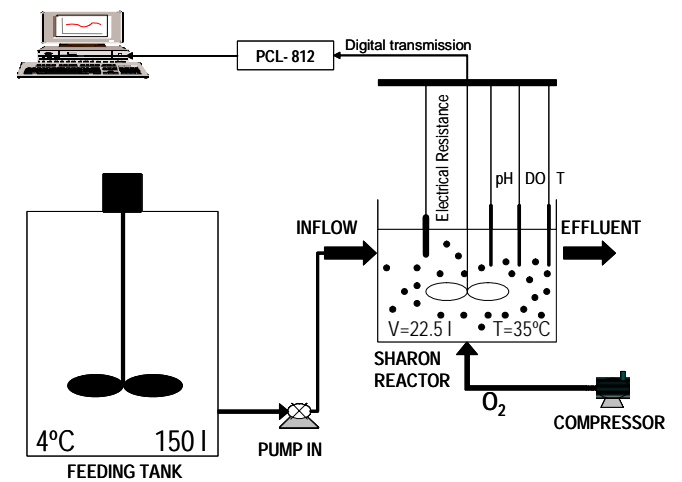

Figure 2. Schematic diagram of the experimental pilot-plant

\subsection{Synthetic substrate and analytical methods}

The synthetic substrate was prepared once per week. This contained about $1 \mathrm{~g} \mathrm{NH}_{4}^{+}-\mathrm{N} \mathrm{l}^{-1}$ with a $\mathrm{NH}_{4}{ }^{+}: \mathrm{HCO}_{3}{ }^{-}$molar ratio of approximately $1: 1$. Furthermore, a phosphate buffer (including $\mathrm{KH}_{2} \mathrm{PO}_{4}$, $\mathrm{K}_{2} \mathrm{HPO}_{4}$ and $\mathrm{Na}_{2} \mathrm{HPO}_{4}$ ) was added to maintain a phosphorus concentration of $12.8 \mathrm{mg} \mathrm{l^{-1 }}$. The $\mathrm{pH}$ ranged from 7.8 to 8.9. This feed was stored in a refrigerated tank to prevent its degradation. Synthetic substrate and effluent were analysed for total suspended solids, volatile suspended solids, total ammonium, nitrites, nitrates and alkalinity, according to Standard Methods (1995).

\section{EVALUATION OF THE MODEL}

A reduced version of the proposed model was used for the evaluation of the 13 kinetic parameters related to nitrifying organisms, and carried out by applying the random direct search method developed by Luus and Jaakola (1973). The objective function to minimize was the sum of the reciprocals of the coefficients of multiple determination $\left(\Sigma\left(1-\mathrm{R}_{\mathrm{i}}^{2}\right)\right)$ of the fitting model for the components: total ammonium, total nitrite, nitrate and $\mathrm{pH}$ using 2 months historical experimental data. A similar procedure is detailed in Flotats et al. (2003). The initial concentrations of nitrifying biomass were also unknown and adjusted during the evaluation. An identifiability study needs to be performed in future, in order to ensure the uniqueness of the calculated parameters.

The specific yield values used were $0.15 \mathrm{~g} \mathrm{COD} \mathrm{g}^{-1} \mathrm{NH}_{4}{ }^{+}-\mathrm{N}$ for ammonium-oxidizers and $0.04 \mathrm{~g}$ $\mathrm{COD} \mathrm{g}{ }^{-1} \mathrm{NO}_{2}^{-}-\mathrm{N}$ for nitrite-oxidizers (Hellinga et al., 1999). Table 5 presents a brief comparison of the adjusted kinetic parameter values and other values from the literature. In some cases, major differences were observed depending on the bibliographic source. Different experimental conditions, biomass adaptation and the kind of kinetic model considered could explain these variations. Literature values of the kinetic parameters related to $\mathrm{N}$ (substrate or inhibitor) can only 
be directly compared with the values adjusted here if the same inhibition model was used, that is with Carrera et al. (2004) for $\mathrm{X}_{\mathrm{AO}}, \mathrm{X}_{\mathrm{NO}}$ and Hellinga et al. (1999) for $\mathrm{X}_{\mathrm{NO}}$.

Table 5. Comparison between the kinetic parameter values obtained and those cited in the literature $\left(35^{\circ} \mathrm{C}\right)$

\begin{tabular}{|c|c|c|c|c|c|c|c|}
\hline Parameter & Units & This study & $\begin{array}{l}\text { Hellinga et al. } \\
\text { (1998) }\end{array}$ & $\begin{array}{l}\text { Hellinga et al. } \\
\text { (1999) }\end{array}$ & $\begin{array}{l}\text { Carrera et al. } \\
\quad(2003)\end{array}$ & $\begin{array}{l}\text { Wett and Rauch } \\
\text { (2003) }\end{array}$ & $\begin{array}{c}\text { Van Hulle et al. } \\
\text { (2004) }\end{array}$ \\
\hline \multicolumn{8}{|c|}{ Ammonium-oxidizers } \\
\hline$\mu_{\mathrm{AO}}$ & $\mathrm{d}^{-1}$ & 4.55 & 2.10 & 2.10 & - & 4.04 & $1.00 \pm 0.2$ \\
\hline $\mathrm{b}_{\mathrm{AO}}$ & $d^{-1}$ & 0.08 & - & - & - & 1.00 & - \\
\hline $\mathrm{K}_{\mathrm{O}_{2}}^{\mathrm{AO}}$ & $\mathrm{mg} \mathrm{O}_{2} \mathrm{l}^{-1}$ & 0.75 & - & 1.45 & - & 0.40 & $0.94 \pm 0.091$ \\
\hline $\mathrm{K}_{\mathrm{NH}_{3}}^{\mathrm{AO}}$ & $\mathrm{mg} \mathrm{N}^{-1}$ & 0.88 & $0.50-7.00$ & 0.468 & $0.20^{\#}$ & $0.13^{\# \#}$ & $0.75 \pm 0.052$ \\
\hline $\mathrm{K}_{\mathrm{I}, \mathrm{NH}}^{\mathrm{AO}}$ & $\mathrm{mg} \mathrm{N}^{-1}$ & 45.8 & - & - & $5.95^{\#}$ & 3000 & - \\
\hline $\mathrm{K}_{\mathrm{I}, \mathrm{HNO}} \mathrm{AO}$ & $\mathrm{mg} \mathrm{N}^{-1}$ & 0.24 & 0.20 & 0.21 & - & 2.80 & $2.04 \pm 0.017$ \\
\hline $\mathrm{K}_{\mathrm{pH}}$ & - & 11.7 & - & - & - & - & - \\
\hline \multicolumn{3}{|c|}{ Nitrite-oxidizers } & & & - & & \\
\hline$\mu_{\mathrm{NO}}$ & $\mathrm{d}^{-1}$ & 1.20 & $0.02-0.17$ & 1.05 & - & 3.21 & - \\
\hline $\mathrm{b}_{\mathrm{NO}}$ & $d^{-1}$ & 0.007 & - & - & - & 0.87 & - \\
\hline $\mathrm{K}_{\mathrm{O}_{2}}^{\mathrm{NO}}$ & $\mathrm{mg} \mathrm{O}_{2} \mathrm{l}^{-1}$ & 1.22 & - & $1.10^{*}$ & - & 1.00 & \\
\hline $\mathrm{K}_{\mathrm{I}, \mathrm{NH}}^{\mathrm{NO}}$ & $\mathrm{mg} \mathrm{N}^{-1}$ & 19.9 & - & - & - & $1.60-20.0$ & - \\
\hline $\mathrm{K}_{\mathrm{HNO}_{2}}^{\mathrm{NO}}$ & $\mathrm{mg} \mathrm{N}^{-1}$ & 0.004 & 0.26 & $1.410^{-3 * *}$ & $1.210^{-4 \#}$ & 0.30 & - \\
\hline $\mathrm{K}_{\mathrm{I}, \mathrm{HNO}} \mathrm{NO}_{2}$ & $\mathrm{mg} \mathrm{N}^{-1}$ & 2.31 & - & $0.27^{*}$ & $0.017^{\#}$ & 2.80 & - \\
\hline
\end{tabular}

${ }^{*}$ Value for $20^{\circ} \mathrm{C} ;{ }^{* *}$ Value for $30^{\circ} \mathrm{C} ;{ }^{\#}$ Value calculated at $\mathrm{pH} 7.5$ and $23^{\circ} \mathrm{C}$; ${ }^{\# \#}$ Value calculated at $\mathrm{pH} 7.3$

A value of $4.55 \mathrm{~d}^{-1}$ for the maximum specific growth rate of ammonium-oxidizers $\left(\mu_{\mathrm{AO}}\right)$ at $35^{\circ} \mathrm{C}$ was obtained. This value is relatively higher than those found in the literature, which may be because, in contrast to other studies, the effect of $\mathrm{pH}$ was taken into account in the corresponding process equation rate. Moreover, despite its low constant value, the decay process was included. The average concentration of ammonia inside the reactor was around $1.5 \mathrm{mg} \mathrm{NH}_{3}-\mathrm{N}^{-1}$ with a peak of $29.1 \mathrm{mg} \mathrm{NH}-\mathrm{N}^{-1}$. The calculated value of the substrate inhibition constant $\left(\mathrm{K}_{\mathrm{I}, \mathrm{NH}_{3}}^{\mathrm{AO}}\right)$ was of 45.8 $\mathrm{mg} \mathrm{NH} \mathrm{NH}_{3} \mathrm{~N}^{-1}$. Therefore, no inhibition due to ammonia in normal working conditions was observed becoming a remarkable phenomenon when $\mathrm{NH}_{3}$ concentrations were high. On the other hand, the $\mathrm{HNO}_{2}$ inhibition constant $\left(\mathrm{K}_{\mathrm{I}, \mathrm{HNO}}^{\mathrm{AO}}\right)$ was equal to $0.24 \mathrm{mg} \mathrm{HNO}_{2}-\mathrm{N}^{-1}$ which denoted nitrous acid inhibition because the average concentration inside the reactor was of approximately $0.20 \mathrm{mg}$ $\mathrm{HNO}_{2}-\mathrm{N}^{-1}$, with a maximum value of $0.43 \mathrm{mg} \mathrm{HNO}_{2}-\mathrm{N}^{-1}$.

The maximum specific growth rate of nitrite-oxidizers $\left(\mu_{\mathrm{NO}}\right)$ at $35^{\circ} \mathrm{C}$ was determined as $1.2 \mathrm{~d}^{-1}$. As in the previous case, the decay constant had a value relatively low. Taking into account the average conditions inside the reactor, total inhibition by $\mathrm{N}$-compounds represented a decrease in the maximum nitratation rate of approximately $15 \%$.

\section{CONCLUSIONS}

A mathematical model capable of predicting the evolution of the variables related to the treatment of wastewaters with high nitrogen contents, and also containing organic matter and phosphorus, in a continuously aerated SHARON reactor is presented. The model includes an algorithm for the calculation of $\mathrm{pH}$, which is a key parameter affecting chemical equilibria, substrates disposal and inhibition phenomena. A preliminary evaluation of the model using synthetic feed was also performed. Inhibitory phenomena due to ammonia and nitrous acid of ammonium-oxidizers and nitrite-oxidizers were detected and explained by the model. Nevertheless, further work is needed in 
order to study the identifiability of parameters and, following an experimental programme designed for this purpose, to calibrate the model using real wastewater rather than synthetic substrate.

\section{ACKNOWLEDGEMENTS}

This work was supported by a grant from the DURSI (Ministry of Universities, Research and Information Society of the Generalitat de Catalunya) and financed by CESPA and the European Union Program LIFE (LIFE 03 ENV/E/000140).

\section{REFERENCES}

Anthonisen A.C., Loehr R.C., Prakasam T.B.S. and Srinath E.G. (1976). Inhibition of nitrification by ammonia and nitrous acid. J. Water Pollut. Con. F. 48(5):835-852.

Campos E. and Flotats X. (2003). Dynamic simulation of pH in anaerobic processes. Appl. Biochem. Biotech. 109:6376.

Carrera J., Jubany I., Carvallo L., Chamy R. and Lafuente J. (2004). Kinetic models for nitrification inhibition by ammonium and nitrite in a suspended and an immobilised biomass systems. Process Biochem. 39:1159-1165.

Flotats X., Ahring B.K. and Angelidaki I. (2003). Parameter identification of thermophilic anaerobic degradation of valerate. Appl. Biochem. Biotech. 109:47-62.

Hellinga C., Schellen A.A.J.C., Mulder J.W., van Loosdrecht M.C.M. and Heijnen J.J. (1998). The SHARON process: an innovative method for nitrogen removal from ammonium-rich waste water. Water Sci. Technol. 37(9):135-142.

Hellinga C., van Loosdrecht M.C.M. and Heijnen J.J. (1999). Model based design of a novel process for nitrogen removal from concentrated flows. Math. Comp. Model. Dyn. 5(4):351-371.

Henze M., Grady C.P.L., Gujer W., Marais G.v.R. and Matsuo T. (1987). Activated Sludge Model Nº 1 . IAWPRC Scientific and Technical Report $\mathrm{N}^{\mathrm{o}}$ 1. London. 33p.

Henze M., Gujer W., Mino T., Matsuo T., Wentzel M.C. and Marais G.v.R. (1995a). Activated Sludge Model N². IAWQ Scientific and Technical Report $\mathrm{N}^{\circ}$ 3. London. 31p.

Henze M., Harremoës P., Jansen J.1.C. and Arvin E. (1995b). Wastewater Treatment: Biological and Chemical Processes. Springer-Verlag. Berlin. 383p.

Lide D.R. (Ed.) (1993). CRC Handbook of Chemistry and Physics. A Ready-Reference Book of Chemical and Physical Data. CRC Press, Inc, $73^{\text {rd }}$ Edition. Boca Raton, USA.

Luus R. and Jaakola T.H.I. (1973). Optimization by direct search and systematic reduction of the size of search region. AIChE J. 19(4):760-766.

Musvoto E.V., Wentzel M.C. and Ekama G.A. (2000). Integrated chemical-physical processes modelling - I. Development of a kinetic-based model for weak acid/base systems. Water Res. 34(6):1857-1867.

Sewell G. (1988). The Numerical Solution of Ordinary and Partial Differential Equations. Academic Press. London.

Snoeyink V.L. and Jenkins D. (1980). Water Chemistry. John Wiley \& Sons, Inc. New York, USA. 480p.

Standard Methods for the Examination of Water and Wastewater (1995). 19 $9^{\text {th }}$ ed. American Public Health Association/American Water Works Association/Water Environment Federation. Washington DC.

van Dongen L.G.J.M., Jetten M.S.M. and van Loosdrecht M.C.M. (2001). The combined Sharon/Anammox process. A sustainable method for N-removal from sludge water. STOWA, IWA Publishing. London. 64p.

Van Hulle S.W.H., Volcke E.I.P., López-Teruel J., Donckels B., van Loosdrecht M.C.M. and Vanrolleghem P.A. (2004). Influence of temperature and $\mathrm{pH}$ on the kinetics of the SHARON nitritation process. $4^{\text {rt }}$ World Water Congress and Exhibition, IWA. Marrakech, Morocco. September, 19-24. (On CD-ROM)

Volcke E.I.P., Hellinga C., Van Den Broeck S., van Loosdrecht M.C.M. and Vanrolleghem P.A. (2002). Modelling the SHARON process in view of coupling with ANAMMOX. TiASWiK'02, Politechnika Gańdska. GdańskSobieszewo, Poland. June, 19-21. 65-72.

Wett B. and Rauch W. (2003). The role of inorganic carbon limitation in biological nitrogen removal of extremely ammonia concentrated wastewater. Water Res. 37(5):1100-1110.

Wyffels S., Van Hulle S.W.H., Boeckx P., Volcke E.I.P., Van Cleemput O., Vanrolleghem P.A. and Verstraete W. (2004). Modeling and simulation of oxygen-limited partial nitritation in a membrane-assisted bioreactor (MBR). Biotechnol. Bioeng. 86(5):531-542. 